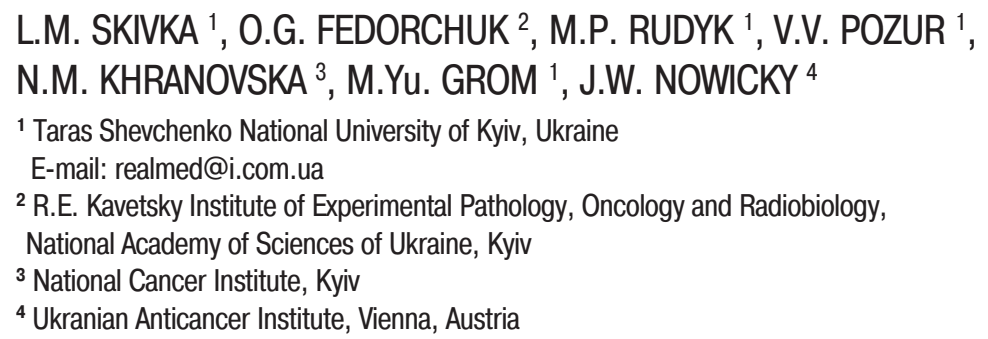

\title{
ANTINEOPLASTIC DRUG NSC631570 MODULATES FUNCTIONS OF HYPOXIC MACROPHAGES
}

Hypoxia is an important factor in the macrophages microenvironment. Many physiological and pathological processes including solid tumor development are characterized by both low oxygen content and presence of macrophages. Tumor-associated hypoxia causes alternative polarization of macrophages in tumor tissue and transformation of these cells into the allies of a malignant neoplasm. The aim of the work was to investigate the effect of NSC631570, a cancerselective drug that is known to selectively accumulate in the tumor tissue, on hypoxic macrophage function. Murine peritoneal macrophages (PMs) were subjected to hypoxia $\left(3 \% \mathrm{O}_{2}\right)$. Nitrite level was assayed by the Griess reaction. Arginase activity was measured by colorimetric method. ROS generation and phagocytosis was estimated by flow cytometry. $\mathrm{O}_{2}^{-}$generation was assayed by the NBT reduction method. HMGB1 expression was determined by ELISA. $42 h$ hypoxia caused alternative polarization of murine PMs with significant arginase prevalence. NSC631570 repolarized arginine metabolism of hypoxic macrophages to NOS dominant and activated their pro-inflammatory functions: recovered ROS production and increased alarmin releaseNSC631570 can restore pro-inflammatory functions of macrophages, alternatively polarized by hypoxia.

Key words: hypoxia, macrophage alternative polarization, NSC631570, oxidative metabolism, phagocytosis, alarmins.

Introduction. Phenotypic and functional heterogeneity is the distinctive feature of macrophages. It is mediated both by the tissue microenvironment and by natural activating stimuli. The plasticity of macrophages can be represented by two extremes in their activation profile, M1 («classical») and M2 («alternative») activation [1, 2]. The M1 profile is induced by IFN- $\gamma$ and microbial products and primarily exhibits microbicidal activity and a pro-inflammatory phenotype [3, 4]. In total, such macrophage activation leads to development

(C) L.M. SKIVKA, O.G. FEDORCHUK, M.P. RUDYK, V.V. POZUR, N.M. KHRANOVSKA, M.Yu. GROM, J.W. NOWICKY, 2013 of the inflammatory process and to induction of the Th1-type immune response [2, 5]. M2 macrophages (induced by IL-4, IL-13, IL-10, TGF $\beta$, glucocorticoid hormones etc.) are characterized by anti-inflammatory properties [6, 7]. The alternative macrophage activation leads to development of the Th2-type immune response. They are better adapted to scavenging of debris, promoting angiogenesis, and repairing and remodeling of wounded/ damaged tissues. Such macrophages practically lose cytotoxic activity [8, 9]. In spite of the MHCIImolecule formation, they are not able to complete antigen-presentation $[1,2,6]$. Instead of this, such cells accomplish the functions of regulatory cells $[10,11]$. The classic and alternative activation of macrophages leads to distinctly directed arginine metabolism. During the classic activation, the inducible nitric oxide synthase (iNOS) metabolizes arginine with NO formation, whereas, during the alternative activation, the Arg-1 arginase enzyme is synthesized which polymerizes arginine to urea and ornithine (a precursor of polyamines and proline) $[12,13]$. Increased arginase activity is considered as a marker of immunosupressive macrophages [14]. An additional criteria of functional polarization of macrophages are the production of reactive oxygen species (ROS) and phagocytic activity. It is admitted that over-expression of receptors involved in phagocytosis: CD163 and CD206 are the markers of alternatively polarized macrophages. Scavenger receptor, CD163, expressed almost exclusively on circulating monocytes and on tissue macrophages, has been recognized as a valuable specific macrophage marker. Tolerogenic macrophages and DC display higher levels of the mannose receptor (CD206) which is another scavenger. The function of CD209 is to recognize complex carbohydrates located on glycoproteins 
that take part in a variety of different biological processes. Some of those processes include cellcell recognition, serum glycoprotein metabolism and neutralization of pathogens. This protein also functions as a type 1 membrane immune receptor that mediates endocytosis of glycoproteins by macrophages. In addition to such receptor function, CD163 and CD206 seem to be involved in performing anti-inflammatory functions which are believed to be predominantly associated with M2 macrophages [15]. ROS generation is a marker of cytotoxic macrophage activity, characteristic for M1 macrophages. Besides, ROS are important regulatory molecules and may influence metabolism of a number of pro-inflammatory molecules including iNOS and danger associated molecular patterns (DAMP) [16].

Hypoxia is an important factor in the macrophage microenvironment. Many physiological and pathological processes (e.g., inflammation, wound healing, acute myocardial infarction, retinopathies, atherosclerosis, solid tumors and more) are characterized by both low oxygen tension (hypoxia) and presence of macrophages. Hypoxia influences different modes of macrophage activation and regulates the shift between them. Macrophages are central participants in hypoxia-driven processes, and the mediators they express and secrete recruit other cells and orchestrate their activity. The role of macrophages and the effects hypoxia exerts on them were studied mostly in solid tumors. Such attention is stipulated by an essential role of tumorassociated macrophages in tumor biology [17]. Macrophages are important effector cells in antitumor immunity [18, 19]. Activated macrophages can infiltrate tumors, express the inducible NOS2, and produce NO, which kills tumor cells [20, 21]. However, presence of macrophages in neoplastic tissue can also lead to their alternative polarization and transformation into the cells-allies of a malignant neoplasm. Such tumor-associated macrophages (TAMs) can promote tumor angiogenesis, facilitate tumor cell invasion, and provide an immunosuppressive tumor microenvironment [18, 22]. TAM activity is therefore likely to be complex and may be influenced by microenvironmental factors, such as cytokines and growth factors produced by tumor cells. Interestingly, TAMs migrate towards and accumulate in hypoxic tumor domains. When exposed to hypoxia, macrophages alter their metabolism implying that tumor hypoxia has a profound influence on TAM functions [23].

NSC-631570 (Ukrain) is a thiophosphoric acid derivative of alkaloids from greater celandine. It exerts cytotoxic and cytostatic effects on cancer cells due to its ability to be selectively accumulated in tumor tissue and activate apoptosis only in malignant cells and not in normal cells [24-27]. This selective uptake of NSC631570 in the cancer cells has been confirmed due to its autofluorescence under UV light. Doroshenko et al. [28] determined the blood plasma and tissue concentrations of the main fluorescent component of free Ukrain after a single intravenous injection of this substance $(0.25 \mathrm{mg} / \mathrm{kg})$ to carcinosarcoma W-256 bearing rats. W-256 tumor tissue was the only tissue that showed accumulation of Ukrain (its concentration at 45 min after injection was up to 2.84-fold higher than that in the blood plasma). Authors suggested that the preparation penetrates into tumor tissue either by active transport or by a favored diffusion. ULA-DC test (UV light excitation and results analysis with the use of AlphaDigiDoc software) revealed that tumor cells consumed much more drug than non-malignant cells [29]. The mechanisms of selective accumulation of the preparation in tumor cells have not yet been fully investigated and understood. Being selectively accumulated in a tumor tissue the preparation can influence TAM function, as TAMs are reported to form about $80 \%$ of the total stromal leucocyte population in solid tumors [14]. In addition, Korolenko et al. $[30,31]$ have shown that NSC-631570 can influence macrophage migration and cause influx of macrophages into the site of its injection and into the tumor growth area after intravenous administration. In our previous investigation we have also observed the ability of the preparation to effect monocyte/macrophage migration [32]. A growing number of studies have described modulating effect of NSC-631570 on macrophage function [33-35]. The preparation stimulates lysosomephagosome fusion and increases the content of polymerized fibrillar form of actin in intact mouse peritoneal macrophages [34]. NSC-631570 used alone or in combination with IFN-gamma increases cytotoxicity of non-sensitized mouse peritoneal macrophages and restores the defective cytotoxic response of peritoneal macrophages of tumor-bearing mice in vitro [35]. 
The aim of the present work was to investigate the effect of NSC-631570 on functional polarization of murine peritoneal macrophages (PMs) exposed to hypoxia in vitro.

Materials and Methods. Isolation and culture of murine PMs. Murine PMs were isolated without preliminary stimulation. Intact mice (male, 8 to 10 weeks old, bred in the vivarium of the Educational and Scientific Center «Institute of Biology» of Taras Shevchenko National University of Kyiv, Ukraine) were sacrificed and PMs were harvested using phosphate buffered saline containing $100 \mathrm{U} / \mathrm{ml}$ of heparin. Cells were centrifuged at $300 \mathrm{~g}$ for $5 \mathrm{~min}$ at $4{ }^{\circ} \mathrm{C}$, washed twice with serum-free DMEM, and re-suspended in DMEM containing $10 \%$ FCS and $40 \mu \mathrm{g} / \mathrm{ml}$ gentamycin. The cells were then seeded into 96-wells flat bottom plates $\left(6 \cdot 10^{5}\right.$ cells/well) and incubated at $37^{\circ} \mathrm{C}$ in a humidified incubator in $95 \%$ air $/ 5 \% \mathrm{CO}_{2}$ for $2 \mathrm{~h}$ to allow the cells to adhere. Non-adherent cells were removed by washing with serum-free DMEM, and adherent cells were further incubated with DMEM-10 \% FCS for hypoxia induction experiments. For short-time investigation of $\mathrm{O}_{2}^{-}$generation adherent cells were resuspended in Hanks buffered saline solution.

Determination of cell viability. Cell viability was determined by Trypan blue exclusion test [36].

Macrophage cultures at different oxygen concentrations. For hypoxia induction experiments, murine PMs were subjected to either normoxia ( $21 \%$ $\left.\mathrm{O}_{2}\right)$ or hypoxia $\left(3 \% \mathrm{O}_{2}\right)$ for the time periods indicated below. Normoxia was controlled by using a humidified $5 \% \mathrm{CO}_{2} /$ air incubator, and hypoxia by pregasing DMEM for $30 \mathrm{~min}$ in a sealed hypoxic work station with $5 \% \mathrm{CO}_{2}$ /balance $\mathrm{N}_{2}$ gas mix and subsequent culture in a humidified hypoxic $\left(\mathrm{CO}_{2} / \mathrm{N}_{2}\right)$ incubator. After the incubation for indicated time period, the cells subjected to normoxia were washed three times in a cold calcium/ magnesium-free PBS and harvested. For cells incubated in hypoxic conditions, these procedures were carried out in a chamber with a constant flow of $\mathrm{CO}_{2} / \mathrm{N}_{2}$ gas mixture. To verify the actual oxygen concentration in the hypoxia incubators, we used an oxygen monitor. To estimate the effect of NSC-631570 on functional polarization of PMs exposed to normoxia and hypoxia the cells were treated with NSC-631570 (Nowicky Farma, Austria) at the concentrations of 20 and $200 \mu \mathrm{g} / \mathrm{ml}$ for
$24 \mathrm{~h}$ in normoxic and hypoxic conditions respectively. Media and cells were harvested after treatment with NSC-631570. Aliquots of media were sampled immediately and analyzed for nitrite and $\mathrm{O}_{2}^{-}$. Arginase activity and intracellular ROS were analysed in harvested cells.

Nitrite assay. Nitrite levels were used as a measure of NO released into the conditioned media of the cells under the various conditions tested. To stimulate the macrophages, lipopolysaccharide (LPS) (from Escherichia coli; Sigma-Aldrich) was added to DMEM to the concentration of $100 \mathrm{ng} / \mathrm{ml}$. After $24 \mathrm{~h}$ of cultivation, the culture supernatants were collected, and the nitrite concentration in each supernatant was assayed by the Griess reaction [37]. Briefly, equal volumes of $2 \%$ sulfanilamide in $10 \%$ phosphoric acid and $0.2 \%$ naphthylethylene diamine dihydrochloride were mixed to prepare the Griess reagent. The reagent $(100 \mu \mathrm{l})$ was added to equal volumes of the supernatant, and the mixture was then incubated for $30 \mathrm{~min}$ at room temperature in the dark. The $A_{550}$ of the formed chromophore was measured with a plate reader. The nitrite content was calculated with sodium nitrite as a standard. Each sample was assayed for nitrite in triplicate. Each value was divided by the number of viable cells and expressed as nitrite level per $10^{6}$ cells. The mean value and SD were calculated with normalized values.

$\mathrm{O}_{2}^{-}$generation assay. $\mathrm{O}_{2}^{-}$generation was assayed by the nitroblue tetrazolium (NBT) reduction method. In a $5 \% \mathrm{CO}_{2}$ atmosphere PMs $\left(2 \cdot 10^{5} /\right.$ well $)$ were incubated for $1 \mathrm{~h}$ at $37^{\circ} \mathrm{C}$ in Hanks buffered saline solution containing $1 \mathrm{mg}$ of NBT per ml, with or without $10^{-9} \mathrm{M}$ phorbol 12-myristate 13-acetate (PMA) as a stimulator of oxidative burst. The optical density at $540 \mathrm{~nm}$ in each well was examined with a plate reader. Each sample was assayed for $\mathrm{O}_{2}^{-}$generation in triplicate, and results are presented as mean $\pm \mathrm{SD}$.

Determination of arginase activity. Arginase activity was measured in cell lysates by standard colorimetric method with some modifications [37]. Briefly, $100 \mu \mathrm{l}$ of $0.1 \%$ Triton X-100 and $100 \mu \mathrm{l}$ of $50 \mathrm{mM}$ Tris- $\mathrm{HCl}(\mathrm{pH} \mathrm{7.5)}$, containing $10 \mathrm{mM} \mathrm{MnCl}_{2}$, were sequentially added to cell samples. Macrophage arginase was then activated by heating of the mixture at $56{ }^{\circ} \mathrm{C}$ for $7 \mathrm{~min}$. The reaction of L-arginine hydrolysis by arginase was carried out by incubation of the mixture contai- 
ning activated arginase, with $100 \mu \mathrm{l}$ of $\mathrm{L}$-arginine $\left(0.5 \mathrm{M}\right.$; pH 9.7) at $37{ }^{\circ} \mathrm{C}$ for $2 \mathrm{~h}$, and was stopped by the addition of $800 \mu$ of the mixture of acidic solution $\left(\mathrm{H}_{2} \mathrm{SO}_{4}: \mathrm{H}_{3} \mathrm{PO}_{4}: \mathrm{H}_{2} \mathrm{O}=1: 3: 7\right)$. For colorimetric determination of urea, a-isonitrosopropiophenone $(40 \mu \mathrm{l}, 9 \%$ solution in ethanol) was added, and the mixture was incubated at $95{ }^{\circ} \mathrm{C}$ for $30 \mathrm{~min}$ and then at $4{ }^{\circ} \mathrm{C}$ for $30 \mathrm{~min}$. The urea concentration was determined spectrophotometrically at $540 \mathrm{~nm}$ with the use of a microplate reader. Each condition was tested in triplicate and the experiments were repeated at least three times. Each value was divided by the number of viable cells and expressed as urea level/h per $10^{6}$ cells. Mean and SD were calculated with normalized values.

Intracellular ROS assay. ROS levels were measured using $2^{\prime} 7^{\prime}$-dichlorodihydro-fluorescein diacetate (carboxy-H2DCFDA, Invitrogen), which is converted into a non-fluorescent derivative (carboxy-H2DCF) by intracellular esterases [38]. Carboxy-H2DCF is membrane impermeable oxidized to fluorescent derivative carboxy-DCF by intracellular ROS. After the indicated treatments, the cells were washed with PBS and incubated with PBS containing $10 \mu \mathrm{M}$ carboxy-H2DCFDA for $20 \mathrm{~min}$ at $37{ }^{\circ} \mathrm{C}$. The loading buffer was then removed, and a short recovery time was allowed for the cellular esterases to hydrolyze the acetoxymethyl ester or acetate groups and render the dye responsive to oxidation. Then the cells were returned to pre-warmed growth medium and incubated for 20 min at $37^{\circ} \mathrm{C}$. Cells were washed twice with PBS, trypsinized, and collected in $1 \mathrm{ml}$ PBS. The cells were then transferred to polystyrene tubes with cell-strainer caps (Falcon, Becton Dickinson) and analyzed with flow cytometry (excitation: $488 \mathrm{~nm}$, emission: $525 \mathrm{~nm}$ ). Only living cells, gated according to scatter parameters, were used for the analysis. PMA was used to stimulate ROS production by macrophages,.

Phagocytosis assay. The flow cytometry phagocytosis assay was performed as described [39] with slight modifications. Staphylococcus aureus Cowan I cells (collection of the Department of Microbiology and General Immunology of Taras Shevchenko National University of Kyiv) were grown on beefextract agar and subsequently were heat inactivated and fluorescein isothiocyanate (FITC) labeled. Peritoneal macrophages were isolated as described above. $100 \mu \mathrm{l}$ of the PMs suspension at the concentration of $2 \cdot 10^{6}$ cells $/ \mathrm{ml}$ was added to each tube. The stock of FITC-labeled $S$. aureus at the concentration of $1 \cdot 10^{7}$ cells $/ \mathrm{ml}$ in the volume of $5 \mu \mathrm{l}$ were added to all tubes. A tube with PMs only served as a negative control. All probes were incubated at $37{ }^{\circ} \mathrm{C}$ for $30 \mathrm{~min}$. At the end of the assay, phagocytosis was arrested by the addition of cold stop solution (PBS with $0.02 \%$ EDTA and $0.04 \%$ paraformaldehyde). Fluorescence of phagocytes with ingested bacteria was determined by flow cytometry. The results were registered as the percentage of cells emitting fluorescence after a defined culture period and as phagocytosis index $(\mathrm{PhI})$ that was calculated by the following formula

$$
\left[\text { Gmean }_{\text {pos }} / \mathrm{P}_{\text {pos }}\right]-\left[\text { Gmean }_{\text {neg }} / \mathrm{P}_{\text {neg }}\right] \text {, }
$$

when $\mathrm{P}_{\text {pos }}$ - percent of positive cells, Gmean ${ }_{\mathrm{pos}}-$ mean channel fluorescence, $\mathrm{P}_{\text {neg }}-$ percent of positive cells in the negative control, Gmean ${ }_{\text {neg }}-$ mean channel fluorescence of the negative control.

ELISA assay. HMGB1 expression was determined in the cell culture supernatant using a specific anti-HMGB1 ELISA (Shino Test Corporation) following the manufacturers protocol. Briefly, $50 \mu \mathrm{l}$ of sample diluent and $50 \mu \mathrm{l}$ of cell culture supernatant were added to each well and incubated at $37{ }^{\circ} \mathrm{C}$ for $24 \mathrm{~h}$. After the incubation, the wells were washed five times with wash buffer and incubated for $2 \mathrm{~h}$ at $25{ }^{\circ} \mathrm{C}$ with $100 \mu \mathrm{l}$ of POD-conjugate solution. Then the wells were further washed five times with a washing buffer and incubated for $30 \mathrm{~min}$ at room temperature with substrate solution. The reaction was stopped by adding $100 \mu \mathrm{l}$ of stop solution to each well and the absorbance was recorded at $450 \mathrm{~nm}$ (the background was excluded by measuring absorbance at $570 \mathrm{~nm}$ ) [40].

Statistical analysis. The statistical significance of the experimental results was determined by Student's t-test. Pearson's test was used to determine correlation coefficient (R2) between HMGB1 release and intracellular ROS generation (GraphPad Prism). For all analyses, $\mathrm{p}<0.05$ was accepted as a significant probability level.

Results and Discussion. Arginine metabolism of macrophages cultured in normoxic and hypoxic condition depends on the time of exposure. Like other cell types, the macrophage response depends on the severity and the duration of the hypoxic exposure. Depending on these characteristics, hy- 


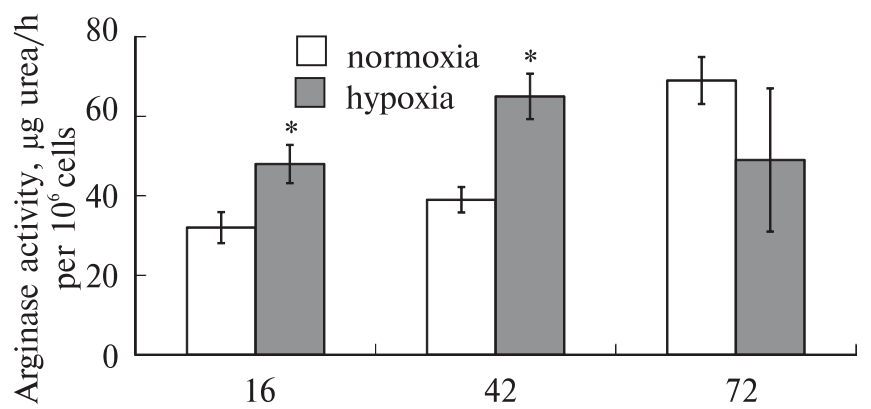

Time of exposure, $h$

$a$

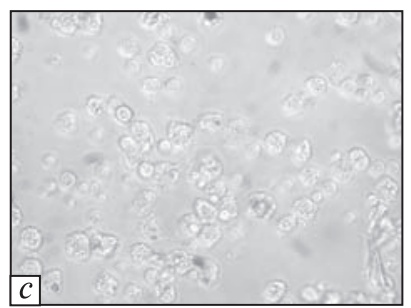

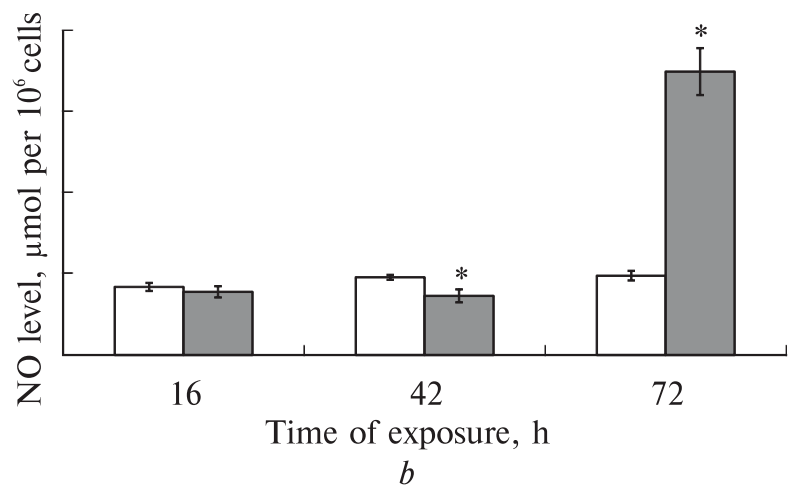

Fig. 1. Effects of the duration of hypoxia exposure on the arginase activity and NO release (measured as nitrite level) by the PMs. Macrophages were cultured under normoxic $\left(21 \% \mathrm{O}_{2}\right)$ and hypoxic $\left(3 \% \mathrm{O}_{2}\right)$ conditions for different time periods. Arginase activity and NO generation (measured by nitrite production) was evaluated to characterize functional polarization of these cells. $a$ - arginase activity ( $\mu \mathrm{mol}$ urea/h per $10^{6}$ cells) was measured in cell lysates as described in "Materials and methods». $b-\mathrm{NO}$ generation. The levels of nitrite were measured by Griess assay. Nitrite level was normalized by the number of viable cells and presented as nitrite level per $10^{6}$ cells. All results are expressed as mean \pm SD of three independent experiments. ${ }^{*} \mathrm{P}<0.05$ was considered significant compared to normoxic cells as analyzed by unpaired Student's t-test; $c$ - PMs cultured under hypoxic conditions for $72 \mathrm{~h}$ became detached from culture plates and their viability was significantly decreased as compared to that in normoxic cells $(d), \times 200$

poxia can drive pro-inflammatory or anti-inflammatory functions of macrophages [41, 42]. The initial experiments were performed to compare the functional state of PMs cultured under normoxic $\left(21 \% \mathrm{O}_{2}\right)$ or hypoxic $\left(3 \% \mathrm{O}_{2}\right)$ conditions for 16 , 24, 42 and $72 \mathrm{~h}$. Arginase activity and production of nitrite was measured to characterize arginine metabolism in these cells. It is known that the isolation procedure may affect the viability of macrophages and their tolerability to further treatment $[43,44]$. For that reason PMs were cultured under normoxic conditions for $4-6 \mathrm{~h}$ to adapt these cells to in vitro conditions before the exposing to different oxygen concentrations. In such a case hypoxia was better tolerated by the PMs. Exposure of the cells to hypoxia for $16 \mathrm{~h}$ did not effect significantly the arginine metabolism polarization in PMs. The metabolism of L-arginine through arginase was greater by 1.5 times in cells cultured in hypoxia conditions compared with those cultured under normoxic conditions (Fig. 1,a). Nitrite was weakly produced by nonactivated cells, either under normoxic or hypoxic conditions. NO production by PMs was unaffected by hypoxia after $16 \mathrm{~h}$ exposure (Fig. 1, b). The absence of significant arginine metabolism polarization was also registered after $24 \mathrm{~h}$ exposure (data not shown). In experiments concerning the effects of hypoxia on functional polarization of phagocytes peripheral blood monocytes or bone marrow derived monocytes (functionally immature cells) are commonly used. These cells polarize metabolism under hypoxic condition for a shorter period of time. PMs are mature tissue phagocytes with more conservative metabolism. Probably, for this reason short-time hypoxia did not effect their function significantly. Moreover functional changes in the cells after a short-term exposure to hypoxia can fully be restored by a brief period of re-oxygenation [45]. We performed all functional tests (in average for $2 \mathrm{~h}$ ) with cells, exposed to both normoxia and hypoxia, under normoxic conditions. Re-oxygenation for this period of time can restore cellular metabolism and could be an additional reason of the absence of significant arginine metabolism polarization after a short-time hypoxia.

More expressed polarization of arginine metabolism of murine PMs was observed after $42 \mathrm{~h}$ hypoxia. Arginase activity in hypoxic cell lysates was ISSN 0564-3783. Цитология и генетика. 2013. T. 47. № 5 
1,7 times higher than that in normoxic cultures. NO level in supernatants of hypoxic PMs was 1.5 times lower than that in supernatants of normoxic cells. Therefore, $42 \mathrm{~h}$ hypoxia polarized PMs function to M2 expression profile. Our results are consistent with the data of literature by which, in contrast to the upregulation of iNOS by hypoxia, NO production is reduced by hypoxia in most cell types. Recent work suggests a prominent role for $\mathrm{O}_{2}$ substrate dependence in the short-term regulation of iNOS-mediated NO production [46]. After a more prolonged hypoxia the expression pathway in the exposed cells was altered from arginase dominant to iNOS dominant. Urea level in lysates of PMs exposed to hypoxia for $72 \mathrm{~h}$ was 1.35 times lower than that after $42 \mathrm{~h}$ hypoxia. It is necessary to point out a significant individual variability of urea levels in supernatants of PMs exposed to hypoxia for $72 \mathrm{~h}$. NO level in supernatants of cells exposed to hypoxia for $72 \mathrm{~h}$ was more than 4 times higher than that after a $42 \mathrm{~h}$ hypoxia and 3.5 times higher than that in normoxic PMs.

We observed that after $72 \mathrm{~h}$ hypoxia treatment $>50 \%$ of PMs became detached from culture plates (Fig. 1, d). The viability of detached macrophages was about $20 \%$ (data not shown). The viability of the attached macrophages was $>90 \%$, which is indicative of living cells. Therefore, prolonged hypoxia proved to be severe for PMs and caused cell death. Cell death, in turn, could be the reason of the pro-inflammatory activation of these cells and, consequently, of an increase of NO production [44]. Degrossoli et al. [47] have shown that selective population of macrophages may adapt to prolonged hypoxic conditions by overcoming the apoptotic signal, and exposition of macrophages to periods of severe hypoxia results in the selection of cells with constitutively elevated NO production.

PMs cultured under normoxic conditions for $72 \mathrm{~h}$ were attached to plates (Fig. 1, c). The viability of these cells was $>80 \%$. The level of arginase activity was 1.77 times higher than that after $42 \mathrm{~h}$ culturing. Macrophage arginase activity was reported by other authors to be significantly elevated by an adaptation of these cells to stress conditions. Arginase hydrolyzes L-arginine to urea and ornithine; the latter being the main intracellular source for synthesis of polyamines necessary for cell growth and survival $[12,13,44]$. In our experiments elevated arginase activity could be considered as a marker of adaptation of PMs to in vitro conditions. The level of nitrite in the probes of PMs cultured under normoxia for $72 \mathrm{~h}$ did not differ from that after 42 $\mathrm{h}$ culturing and was, as before, rather low. Taking into account the high level of cell death in PMs exposed to hypoxia for $72 \mathrm{~h}$, we used only $42 \mathrm{~h}$ hypoxia in our further experiments.

Oxidative metabolism, phagocytosis and HMGB1 release in macrophages cultured at different oxygen concentrations. Both hypoxia and hyperoxia may favor overproduction of ROS. Significant formation of reactive oxygen species was observed in tumor zones of intermittent hypoxia and reperfusion. Though, prolonged severe hypoxia can decrease ROS production [16, 48].

In our experiments we have investigated spontaneous and stimulated (with PMA) intracellular ROS formation and extracellular $\mathrm{O}_{2}^{-}$generation (in NBT-test) by macrophages exposed to $42 \mathrm{~h}$ hypoxia. The level of intracellular ROS in PMs after $42 \mathrm{~h}$ hypoxia was insignificantly lower than that in the cells cultured for the same period of time under normoxic conditions (Fig. 2, a). Treatment of hypoxic cells with PMA failed to stimulate ROS production. Whereas, PMs cultured under normoxic conditions for $42 \mathrm{~h}$ exhibited significantly higher ROS level after stimulation with PMA.

Extracellular $\mathrm{O}_{2}^{-}$generation was also affected by hypoxia (Fig. 2,b). Spontaneous $\mathrm{O}_{2}^{-}$generation in PMs cultured under hypoxic condition for $42 \mathrm{~h}$ was $30 \%$ lower than that in the cells cultured under normoxia. Treatment of PMs exposed to hypoxia with PMA failed to stimulate extracellular $\mathrm{O}_{2}^{-}$generation, whereas treatment of PMs cultured under normoxic conditions for $42 \mathrm{~h}$ with PMA resulted in a significant stimulation of oxidative burst.

The effect of hypoxia itself on the process of phagocytosis remains largely unexplored and controversial. A number of systemic inflammatory diseases are accompanied by development of hypoxia and are associated with bacterial suprainfection, raising the question that phagocytosis may also be impaired in these hypoxic processes. At the same time hypoxia was found to cause the activation of intracellular signaling pathways, which themselves may regulate phagocytosis and can enhance phagocytosis in macrophages in a HIF-1-dependent manner [49]. In our experiments we have investigated spontaneous and stimulated (with LPS) phagocy- 

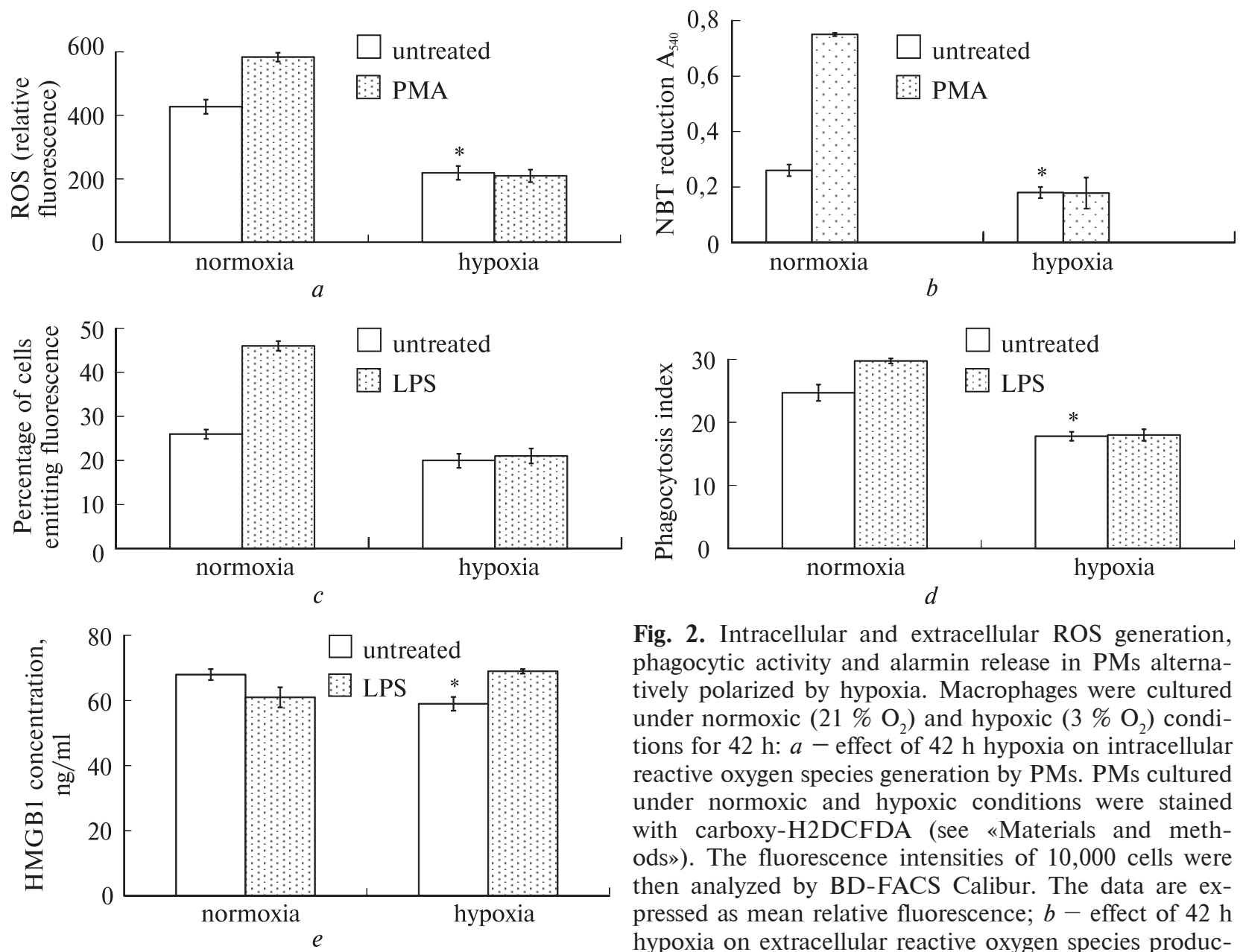

Fig. 2. Intracellular and extracellular ROS generation, phagocytic activity and alarmin release in PMs alternatively polarized by hypoxia. Macrophages were cultured under normoxic $\left(21 \% \mathrm{O}_{2}\right)$ and hypoxic $\left(3 \% \mathrm{O}_{2}\right)$ conditions for $42 \mathrm{~h}$ : $a$ - effect of $42 \mathrm{~h}$ hypoxia on intracellular reactive oxygen species generation by PMs. PMs cultured under normoxic and hypoxic conditions were stained with carboxy-H2DCFDA (see «Materials and methods»). The fluorescence intensities of 10,000 cells were then analyzed by BD-FACS Calibur. The data are expressed as mean relative fluorescence; $b$ - effect of $42 \mathrm{~h}$ hypoxia on extracellular reactive oxygen species production by PMs. Oxidative burst was evaluated by NBT-test. The results are presented as the extent of NBT reduction. PMA was used to stimulate oxidative metabolism; $c, d$ - phagocytic activity of PMs exposed to 42 h hypoxia. Phagocytosis was analysed by flow cytometry with the use of FITC-labeled $S$. aureus. Phagocytic activity was assessed as a number of fluorescence emitting cells $(c)$ and as a phagocytosis index $(d)$ as described in «Materials and methods»; $e-$ effect of $42 \mathrm{~h}$ hypoxia on HMGB1 release by PMs. Release of HMGB1 was assessed in the cell culture supernatant by ELISA. All the results are expressed as mean $\pm \mathrm{SD}$ of three independent experiments. ${ }^{*} \mathrm{P}<0.05$ was considered significant compared to normoxic cells as analysed by unpaired Student's t-test

tosis by PMs exposed to $42 \mathrm{~h}$ hypoxia and have analyzed a number of cells emitting fluorescence (phagocytic number) and phagocytosis index (see «Materials and methods»).

As shown in Fig. 2, c, exposure of PMs to hypoxia for $42 \mathrm{~h}$ had no effect on a number of phagocyting cells. In contrast, phagocytosis index of hypoxic PMs at this time point was $28 \%$ lower than that in normoxic cells (Fig. 2, d). Treatment of hypoxic PMs with LPS did not exert any significant effect on phagocytic activity and the phagocytosis intensity. At the same time, statistically significant increase of a number of phagocyting cells and phagocytosis index in response to treatment with LPS was observed in normoxic PMs.

High-mobility group box 1 (HMGB1) is a ubiquitous nuclear protein that can be released by any damaged cell or by activated macrophages and certain other cell types. HMGB1 is a member of a subfamily of the HMG proteins. HMG proteins are constitutively expressed in the nucleus of eukaryotic cells. Like other members of this protein family, HMGB1 plays an important role in DNA architecture and transcriptional regulation. Extracellular HMGB1 has apparently contrasting biological actions: it sustains inflammation (with the possible establishment of autoimmunity or of 


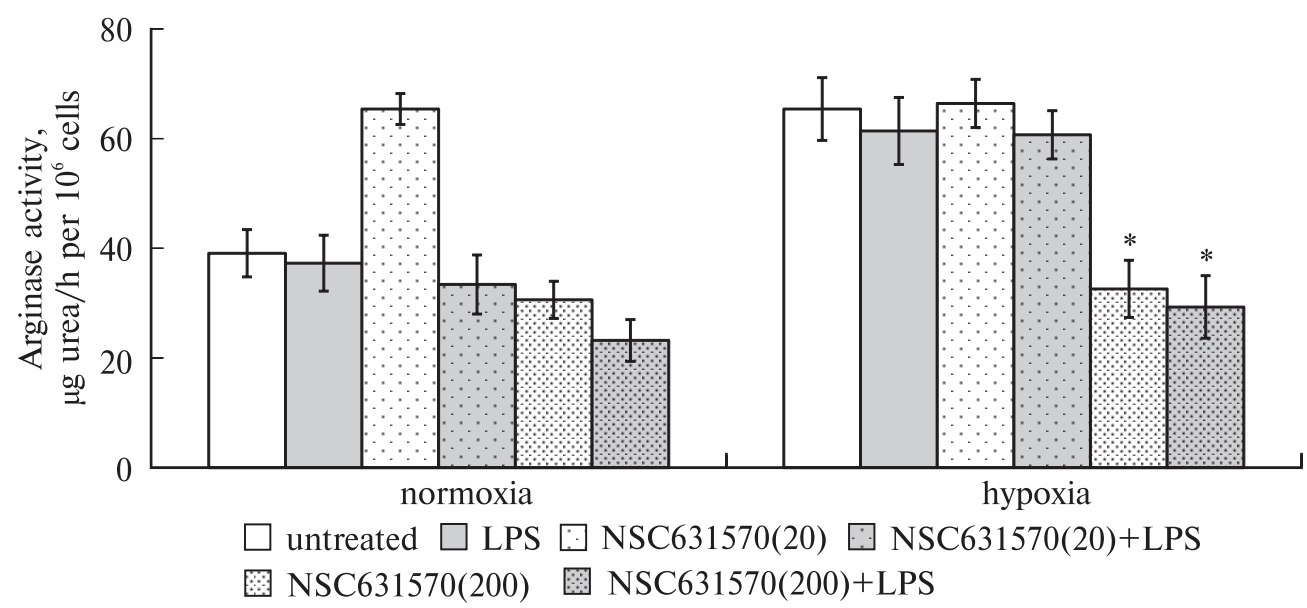

$a$

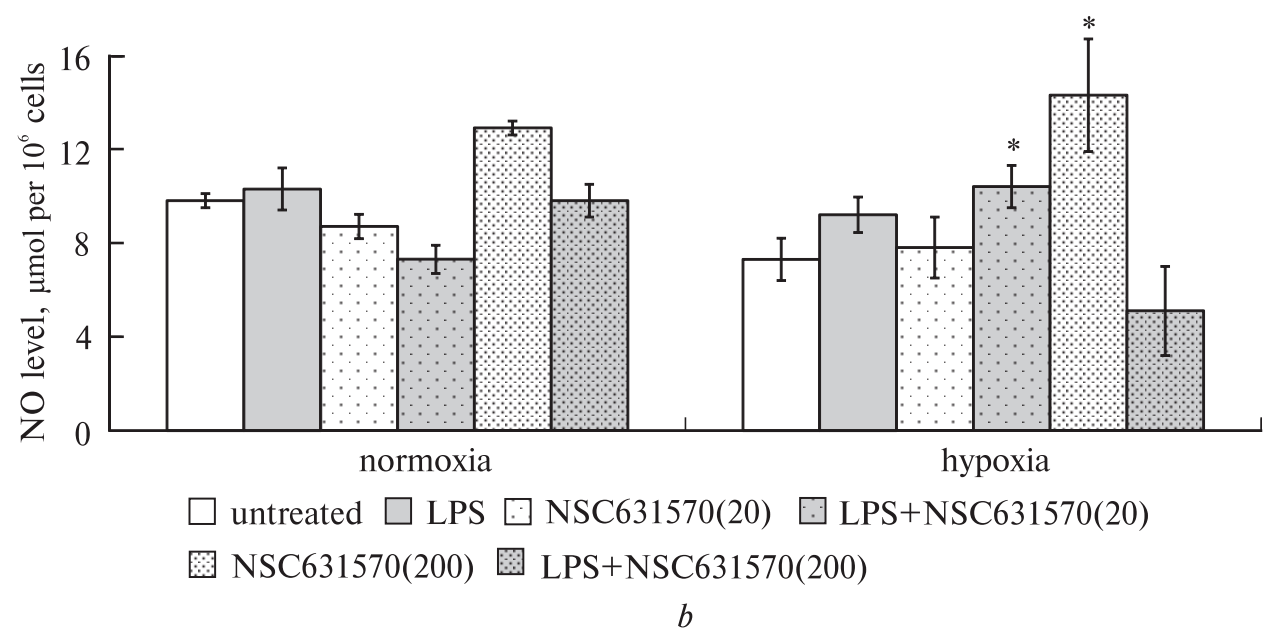

Fig. 3. Effects of NSC631570 at the different concentrations on arginase activity and NO release (measured as nitrite level) by the PMs cultured under hypoxic conditions. Macrophages were cultured under normoxic $\left(21 \% \mathrm{O}_{2}\right)$ and hypoxic $\left(3 \% \mathrm{O}_{2}\right)$ conditions for $42 \mathrm{~h}$. LPS was used to stimulate nitrite production. To estimate the effect of NSC631570 on arginine metabolism of PMs exposed to normoxia and hypoxia, cells were treated with the drug at the concentrations of $20 \mu \mathrm{g} / \mathrm{ml}$ and $200 \mu \mathrm{g} / \mathrm{ml}$ for $24 \mathrm{~h}$ in normoxic and hypoxic condition respectively: $a-$ arginase activity ( $\mu \mathrm{mol}$ urea/h per $10^{6}$ cells) was measured in cell lysates as described in «Materials and methods»; $b-$ the levels of nitrite were measured by Griess assay. Nitrite level was normalized by the number of viable cells and presented as nitrite level per $10^{6}$ cells. All the results are expressed as mean $\pm \mathrm{SD}$ of three independent experiments. ${ }^{*} \mathrm{P}<0.05$ was considered significant compared to untreated hypoxic cells as analysed by unpaired Student's t-test

a self-maintaining tissue damage) while by activating and recruiting stem cells, it fosters tissue repair [49, 50]. As HMGB1 has multiple downstream signaling responses due to activation of different receptors, it also induces cell specific responses when it stimulates cells of the immune system. HMGB1 induces dendritic cells maturation as measured by the increased expression of many cell surface markers, as well as the secretion of inflammatory cytokines. Monocytes and neutrophils stimulated with HMGB1 have an in- creased capacity for adhesion and release numerous cytokines and inflammatory mediators.

HMGB1 is integral to oxidative stress. Release of this protein from cultured cells was found to be an active process regulated by reactive oxygen species (ROS) [51, 52]. We found that HMGB1 level in the culture supernatants of hypoxic PMs was significantly lower than that in their normoxic counterparts (Fig. 2,e). Treatment of macrophages with LPS did not effect alarmin release under normoxia 

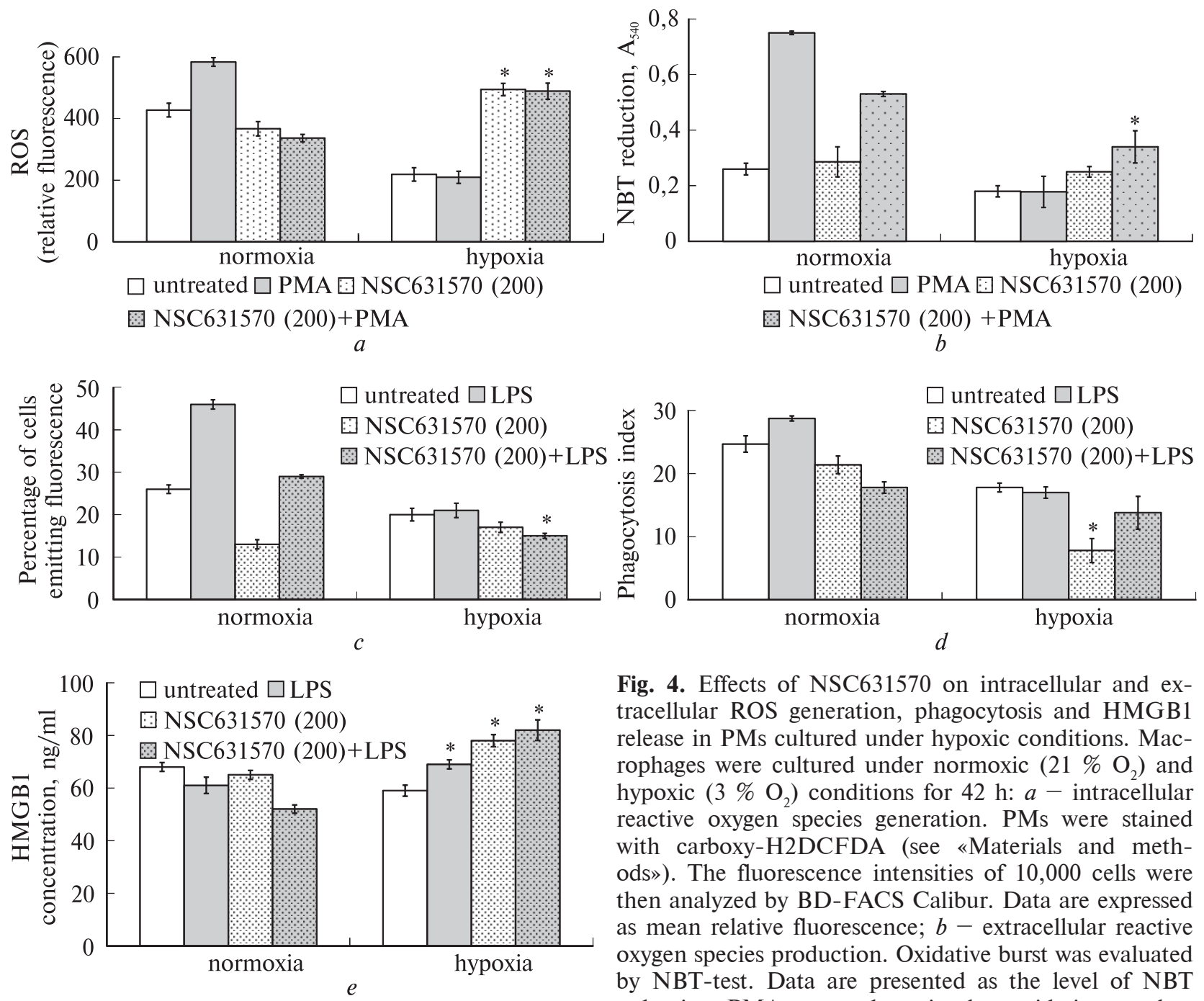

Fig. 4. Effects of NSC631570 on intracellular and extracellular ROS generation, phagocytosis and HMGB1 release in PMs cultured under hypoxic conditions. Macrophages were cultured under normoxic $\left(21 \% \mathrm{O}_{2}\right)$ and hypoxic $\left(3 \% \mathrm{O}_{2}\right)$ conditions for $42 \mathrm{~h}: a-$ intracellular reactive oxygen species generation. PMs were stained with carboxy-H2DCFDA (see «Materials and methods»). The fluorescence intensities of 10,000 cells were then analyzed by BD-FACS Calibur. Data are expressed as mean relative fluorescence; $b$ - extracellular reactive oxygen species production. Oxidative burst was evaluated by NBT-test. Data are presented as the level of NBT reduction. PMA was used to stimulate oxidative metabolism; $c, d$ - phagocytic activity. Phagocytosis was analysed by flow cytometry with the use of FITC-labeled $S$. aureus. Phagocytic activity was assessed as a number of cells emitting fluorescence $(\%)(c)$ and as a phagocytosis index $(d)$ as described in «Materials and methods»; $e$ - effect of $42 \mathrm{~h}$ hypoxia on HMGB1 release by PMs. Release of HMGB1 was assessed in the cell culture supernatant by ELISA. All results are expressed as mean \pm SD of three independent experiments. $* \mathrm{P}<0.05$ was considered significant compared to untreated hypoxic cells as analysed by unpaired Student's t-test

but caused significant increase of HMGB1 release in hypoxic cells. Taking into account interdependence between ROS and alarmins release Pearson correlation analysis was used to determine the correlation coefficient (R2) between the concentration of HMGB1 in the cell supernatants and intracellular ROS generation in PMs exposed to $42 \mathrm{~h}$ hypoxia. The levels of HMGB1 in the probes of untreated hypoxic cells exhibited strong correlation $(\mathrm{R} 2=0.94, \mathrm{P}<0.05)$ with the levels of ROS. Un-

like in the probes of hypoxic cells treated with LPS, the correlation between HMGB1 level and ROS level was absent. It indicates that the mechanisms of LPS-mediated increase of HMGB1 release in hypoxic cells did not depend on intracellular ROS generation.

In our further experiments we investigated the effect of NSC631570 on functional state of PMs cultured under normoxic and hypoxic conditions for 42 and $72 \mathrm{~h}$. 
NSC631570 repolarizes arginine metabolism in hypoxia exposed PMs in a dose-dependent manner. Taking into consideration the low levels of nitrite production by non-activated cells we have used LPS to stimulate arginine metabolism in both normoxic and hypoxic PMs. As it was shown above, $42 \mathrm{~h}$ hypoxia polarized arginine metabolism of PMs to the arginase dominant. Treatment of normoxic and hypoxic cells with LPS had no effect on the arginase activity. The effect of NSC631570 on arginase activity of PMs depended on the concentration of the preparation. In our experiments we have used two concentrations of the preparation: $20 \mu \mathrm{g} / \mathrm{ml}$ (the minimal concentration apoptogenic for tumor cells) and $200 \mu \mathrm{g} / \mathrm{ml}$ (concentration of the preparation that causes death of $90 \%$ of tumor cells in vitro) [32]. Urea levels in lysates of hypoxic phagocytes treated with NSC631570 at the concentration of $20 \mu \mathrm{g} / \mathrm{ml}$ for $24 \mathrm{~h}$ did not differ from that in lysates of untreated hypoxic cells. Incubation of normoxic phagocytes with NSC631570 at the low concentration led to increase of arginase activity. Treatment of hypoxic PMs with NSC631570 at the concentration of 200 $\mu \mathrm{g} / \mathrm{ml}$ resulted in decrease of arginase activity to the normoxic cell level (Fig. 3, a). Urea levels in the probes of normoxic cells treated with the drug at high concentration did not differ from that in the untreated cells.

Fig. 3, $b$ shows the production of nitrite by PMs. As mentioned above, the non-activated cells show low production of nitrite. For this reason, we have used LPS to stimulate NO production. Surprisingly, treatment of PMs cultured under normoxia with LPS failed to stimulate NO production. After challenge of hypoxic cells with LPS, the nitrite production was observed to increase insignificantly. NSC631570 $(20 \mu \mathrm{g} / \mathrm{ml})$ did not effect nitrite production in both normoxic and hypoxic cells. The preparation at the concentration of $200 \mu \mathrm{g} /$ $\mathrm{ml}$ increased NO production 1.3 times in normoxic cells and about 2 times in hypoxic macrophages. Treatment of normoxic PMs with NSC631570 at the concentration of $20 \mu \mathrm{g} / \mathrm{ml}$ in combination with LPS resulted in significant decrease of nitrite production. In contrast, treatment of hypoxic cells with the combination of these preparations led to increase of NO production. Culturing of normoxic macrophages with LPS in combination with NSC631570 at the high concentration had no ef- fect on nitrite production, whereas in hypoxic cells this treatment caused significant decrease of NO level in cell supernatants.

Taking into account that NSC631570 at the concentration of $200 \mu \mathrm{g} / \mathrm{ml}$ exerted more expressed effect on hypoxic macrophage functional polarization than at the concentration of $20 \mu \mathrm{g} / \mathrm{ml}$, we have used only high concentration of the preparation to estimate its effect on oxidative metabolism, phagocytosis and HMGB1 release.

NSC631570 modulates oxidative metabolism, phagocytic activity and alarmin release in hypoxia exposed $P M s$. In our previous investigation we have observed a dose-dependent modulation of oxidative metabolism of intact murine peritoneal macrophages caused by short-term $(1 \mathrm{~h})$ treatment with the preparation [data in press]. NSC631570 was found to restore cytotoxic activity of peritoneal macrophages of tumor-bearing animals in vitro after short-term incubation [35]. In the present experiment PMs cultured under normoxia and hypoxia were treated with the preparation for $24 \mathrm{~h}$. As shown in Fig. 4, a, NSC631570 considerably enhanced intracellular ROS generation in hypoxic cells but did not effect significantly this characteristic in PMs cultured under normoxia. Treatment of hypoxic PMs with NSC631570 in combination with PMA also resulted in substantial increase of ROS generation, whereas this treatment led to decrease of intracellular ROS generation in normoxic cells. Effect of NSC631570 on extracellular ROS production by PMs differed from that on intracellular ROS generation. Used alone, the preparation did not influence oxidative burst in both normoxic and hypoxic PMs. However, if used in combination with LPS, the preparation appreciably potentiated the stimulatory effect of the latter on PMs cultured under hypoxic conditions and inhibited LPS-mediated stimulation of the oxidative burst in normoxic cells.

Used alone, NSC631570 exerted inhibitory effect on phagocytic activity of PMs irrespective of the conditions of cell culturing. Moreover, the preparation decreased stimulatory effect of LPS when they were used in combination. However, the pattern of inhibitory effect of NSC631570 on hypoxic cells differed from that on the normoxic ones. In hypoxic cells supressive effect of the preparation was more expressed towards phagocytosis intensity (phagocytosis index in treated cells was 2.3 times lower than that in the untreated cells), whereas in 
normoxic PMs NSC631570 largely (by 2 times) reduced a number of phagocyting cells.

As for HMGB1 release, we have found that its level in the culture supernatants of hypoxic cells treated with NSC631570 was significantly higher than that in untreated cells and than that in the cells treated with LPS. Used in combination with LPS, the preparation also increased alarmin release. The levels of HMGB1 in the cell probes treated with NSC631570 in combination with LPS were higher than those in supernatants of cells treated with these drugs separately. It indicates synergistic effect of NSC631570 and LPS on alarmin release by alternatively polarized hypoxic macrophages.

Conclusions. NSC631570 repolarized arginine metabolism of alternatively polarized hypoxic macrophages and activated their pro-inflammatory functions: recovered ROS production and increased alarmin release. According to earlier publications [24-27], NSC631570 has an ability to be selectively accumulated in tumor tissues, where TAMs (cells alternatively polarized by tumor microenvironment including tumor-associated hypoxia) may constitute up to $80 \%$ of the total stromal leucocyte population. Therefore we cannot rule out the possibility that the preparation can influence TAM functions and recover their antitumor potential. Effect of hypoxia on functional polarization of murine peritoneal macrophages depended on the duration of exposure. Only $42 \mathrm{~h}$ hypoxia caused alternative polarization of murine PMs with reliable arginase dominant. Alternative polarization of arginine metabolism was accompanied by significant decrease of intracellular and extracellular ROS production, slight reduction of alarmins and moderate lowering of phagocytic activity of hypoxic cells. Our findings provide new insight on the mechanisms of NSC631570 antitumor effect and suggest that the preparation not only kills tumor cells but also has an ability to restore the role of TAMs in antitumor defence.

Л.М. Скивка, А.Г. Федориук, М.П. Рудык, В.В. Позур, Н.Н. Храновская, М.Ю. Гром, Я.В. Новицкий

ПРОТИВООПУХОЛЕВЫЙ ПРЕПАРАТ NSC631570 МОДУЛИРУЕТ ФУНКЦИИ ГИПОКСИЧЕСКИХ МАКРОФАГОВ

Гипоксия является важным фактором микроокружения макрофагов. Многие физиологические и патологические процессы, в том числе рост солидных опухолей, характеризуются низким давлением кислорода и присутствием макрофагов. Опухолеассоциированная гипоксия является одной из причин альтернативной поляризации макрофагов в опухолевой ткани, превращая их в клетки-союзники опухолевого процесса. Целью работы было исследование влияния NSC631570 - опухоле-селективного препарата со способностью избирательно накапливаться в опухолевой ткани - на функции гипоксических макрофагов. Мышиные перитонеальные макрофаги (ПМ) подвергались гипоксической обработке $\left(3 \% \mathrm{O}_{2}\right)$. Уровень нитритов исследовали в реакции Грисса. Аргиназную активность определяли колориметрическим методом. Образование внутриклеточных реактивных форм кислорода (РФК) и фагоцитоз анализировали с помощью проточной цитофлюориметрии. Внеклеточную продукцию РФК определяли в НСТ-тесте, экспрессию HMGB1 - методом ELISA. 42-часовая гипоксия обусловливала альтернативную поляризацию ПМ с преобладанием аргиназной активности. NSC631570 вызывал реполяризацию метаболизма аргинина в гипоксических ПМ и активировал их провоспалительные функции: усиливал кислород-зависимый метаболизм и выделение аларминов. NSC631570 способен восстанавливать провоспалительные функции макрофагов, альтернативно поляризованных гипоксией.

Л.М. Сківка, О.Г. Федорчук, М.П. Рудик, В.В. Позур, Н.М. Храновська, М.Ю. Гром, Я.В. Новицький

\section{ПРОТИПУХЛИННИЙ ПРЕПАРАТ NSC631570 МОДУЛЮЕ ФУНКЦІЇ ГІПОКСИЧНИХ МАКРОФАГІВ}

Гіпоксія $є$ важливим фактором мікрооточення макрофагів. Багато важливих фізіологічних і патологічних процесів, у тому числі ріст солідних пухлин, характеризуються низьким тиском кисню i присутністю макрофагів. Пухлино-асоційована гіпоксія є однією з причин альтернативної поляризації макрофагів у пухлинній тканині, перетворюючи їх на клітини-союзники пухлинного процесу. Метою роботи було дослідження впливу NSC631570 пухлино-селективного препарату зі здатністю вибірково накопичуватись у пухлинній тканині на функції гіпоксичних макрофагів. Мишачі перитонеальні макрофаги (ПМ) піддавались гіпоксичній обробці (3 \% $\mathrm{O}_{2}$ ). Рівень нітритів вивчали в реакції Гріса. Аргіназну активність визначали колориметричним методом. Утворення внутрішньоклітинних реактивних форм кисню (РФК) і фагоцитоз аналізували за допомогою проточної цитофлюориметpiï. Позаклітинну продукцію РФК визначали в НСТтесті, експресію HMGB1 - методом ELISA. 42-годинна гіпоксія спричиняла альтернативну поляризацію ПМ з переважанням аргіназної активності. 
NSC631570 викликав реполяризацію метаболізму аргініну у гіпоксичних ПМ і активував їх прозапальні функції: посилював кисне-залежний метаболізм і виділення алармінів. NSC631570 здатний відновлювати прозапальні функції макрофагів, альтернативно поляризованих гіпоксією.

\section{REFERENCES}

1. Martinez F.O., Sica A., Mantovani A., Locat M. Macrophage activation and polarization // Front. Biosci. - 2008. - 13. - P. 453-461.

2. Murray P.J., Wynn T.A. Obstacles and opportunities for understanding macrophage polarization // J. Leukoc. Biol. - 2011. - 89, № 4. - P. 557-563.

3. Mahdavian Delavary B., van der Veer W.M., van Egmond M., Niessen F.B., Beelen R.H. Macrophages in skin injury and repair // Immunobiology. - 2011. 216, № 7. - P. 753-762.

4. Mege J.L., Capo C. Is macrophage polarization the Gordian knot of bacterial infections? // Med. Sci. 2010. - 26, № 1. - P. 83-88.

5. Jeneway C.A., Travers P., Walport M., Shlomchik M. Immunobiology: The Immune System in Health and Disease. - New York, London : Garland Publ., 2002.

6. Fairweather D., Cihakova D. Alternatively activated macrophages in infection and autoimmunity // J. Autoimmun. - 2009. - 33, № 3/4. - P. 222-230.

7. Varin A., Gordon S. Alternative activation of macrophages: immune function and cellular biology // Immunobiology. - 2009. - 214, № 7. - P. 630641.

8. Stout R.D., Watkins S.K., Suttles J. Functional plasticity of macrophages: in situ reprogramming of tumor-associated macrophages // J. Leukoc. Biol. 2009. - 86, № 5. - P. 1105-1109.

9. Biswas S.K., Mantovani A. Macrophage plasticity and interaction with lymphocyte subsets: cancer as a paradigm // Nat. Immunol. - 2010. - 11, № 10. P. 889-896.

10. Mantovani A., Sica A., Allavena P. et al. Tumor-associated macrophages and the related myeloid-derived suppressor cells as a paradigm of the diversity of macrophage activation // Hum. Immunol. - 2009. - 70, № 5. - P. 325-330.

11. Fujimura T., Mahnke K., Enk A.H. Myeloid derived suppressor cells and their role in tolerance induction in cancer // J. Dermatol. Sci. - 2010. - 59, № 1. P. 1-6.

12. Mielczarek-Puta M., Chrzanowska A., Graboń W., Barańczyk-Kuźma $A$. New insights into arginase. 2. Role in physiology and pathology // Postepy Hig Med Dosw (Online). - 2008. - 14, № 62. - P. 214221.

13. Mills C.D. Macrophage arginine metabolism to ornithine/urea or nitric oxide/citrulline: a life or death issue // Crit. Rev. Immunol. - 2001. - 21, № 5. P. 399-425.

14. Cassetta L., Cassol E., Poli, G. Macrophage polarization in health and disease // Sci. World J. - 2011. 11. - P. 2391-2402.

15. Moestrup S.K., Muller H.J. CD163: a regulated hemoglobin scavenger receptor with a role in the antiinflammatory response // Ann. Med. - 2004. - 36, № 5. - P. 347-354.

16. Brüne B., Zhou J. Nitric oxide and superoxide: interference with hypoxic signaling // Cardiovasc. Res. 2007. - 75, № 2. - P. 275-282.

17. Rahat M.A., Bitterman H., Lahat N. Molecular mechanisms regulating macrophage response to hypoxia // Front Immunol. - 2011. - 2. - P. 45.

18. Lindenberg J.J., Fehres C.M., van Cruijsen H. et al. Cross-talk between tumor and myeloid cells: how to tip the balance in favor of antitumor immunity // Immunotherapy. - 2011. - 3, № 1. - P. 77-96.

19. Yuan A., Chen J.J., Yang P.C. Pathophysiology of tumor-associated macrophages // Adv. Clin. Chem. 2008. - 45. - P. 199-223.

20. Mantovani A., Sica A. Macrophages, innate immunity and cancer: balance, tolerance, and diversity // Curr. Opin. Immunol. - 2010. - 22, № 2. - P. 231-237.

21. Weigert A., Brüne B. Nitric oxide, apoptosis and macrophage polarization during tumor progression // Nitric Oxide. - 2008. - 19, № 2. - P. 95-102.

22. Sica A., Larghi P., Mancino A. et al. Macrophage polarization in tumour progression, Semin // Cancer Biol. - 2008. - 18, № 5. - P. 349-355.

23. Murdoch C., Lewis C.E. Macrophage migration and gene expression in response to tumor hypoxia // Int. J. Cancer. - 2005. - 117, № 5. - P. 701-708.

24. Todor I. The effect of the antineoplastic drug NSC631570 on the electrokinetic potential of malignant and normal cells // Int. J. Immunother. - 2003. 19, № 2/4. - P. 159-167.

25. Ernst E., Schmidt K. Ukrain - a new cancer cure? A systematic review of randomised clinical trials // BMC Cancer. - 2005. - 5. - P. 1-7.

26. Venkatesh K., Govindaraj S., Ramachandran A. et al. Effect of ukrain on cell survival and apoptosis in the androgen-independent prostate cancer cell line PC-3 // J. Environ. Pathol. Toxicol. Oncol. - 2011. 30, № 1. - P. 11-19.

27. Habermehl D., Kammerer B., Handrick R. et al. Proapoptotic activity of Ukrain is based on Chelidonium majus L. alkaloids and mediated via a mitochondrial death pathway // BMC Cancer. - 2006. - 6. P. 14.

28. Doroshenko Y.M., Karavay A.V., Hodysh Y.Y. et al. The dynamics of concentration of the main fluorescent component of Ukrain in the tissues and blood plasma of rats with W-256 tumor after a single intra- 
venous injection // Drugs Exp. Clin. Res. - 2000. 26, № 5/6. - P. 171-177.

29. Funel N., Giovannetti E., Nowicky W. et al. Different uptake of NSC631570 can explain the selective effect against pancreatic adenocarcinoma cell cultures in vitro // J. Pancreas (Online) 2010. - 11, № 5 P. 498-535.

30. Korolenko T.A., Svechnikova I.G., Filjushina E.E. et al. Macrophage stimulation and antitumor effect of Ukrain // Drugs Exp. Clin. Res. - 1998. - 24 № 5/6. - P. 253-260.

31. Poteriaeva O.N., Korolenko T.A., Svechnikova I.G. et al. Cysteine proteinases and their inhibitors in the development of mouse HA-1 hepatoma and antineoplastic therapy // Biomed. Khim. - 2004. - 50, № 2. - P. 172-179.

32. Skivka L., Susak Y., Trompak O. et al. The effect of monotherapy and combined therapy with NSC631570 (Ukrain) on growth of low- and high-metastasizing B16 melanoma in mice // J. Oncol. Pharm. Pract. - 2011. - 17, № 4. - P. 339-350.

33. Liepins A., Nowicky J.W. Modulation of immune effector cell cytolytic activity and tumour growth inhibition in vivo by Ukrain (NSC 631570) // Drugs Exp. Clin. Res. - 1996. - 22, № 3/5. - P. 103-113.

34. Mozhenok T.P., Beliaeva T.N., Leont'eva E.A., Faddeeva M.D. Effect of alkaloid sanguinarine and a pharmaceutical preparation ukrain on modulation of vesicular membrane fusion and actin cytoskeleton of macrophages // Tsitologia. - 2005. - 47, № 10. P. 860-865.

35. Grinevich Y., Shalimov S., Bendyuh G. et al. Effect of Ukrain on the growth and metastasizing of Lewis carcinoma in C57BL/6 mice // Drugs Exp. Clin. Res. 2005. - 31, № 2. - P. 59-70.

36. Mosmann T.R. Rapid colorimetric assay for cellular growth and survival: application to proliferation and cytotoxicity assay // J. Immunol. Meth. - 1983. 65. - P. 55-63.

37. Macrophages and dendritic cells : Methods and protocols / Ed. E.R. Neil. - New York : Humana Press, 2009. - 368 p.

38. Woo J.M., Shin D.Y., Lee S.J. et al. Curcumin protects retinal pigment epithelial cells against oxidative stress via induction of heme oxygenase-1 expression and reduction of reactive oxygen // Mol. Vis. 2012. - 18. - P. 901-908.

39. Cantinieaux B., Hariga C., Courtoy P. et al. Staphylococcus aureus phagocytosis. A new cytofluorometric method using FITC and paraformaldehyde // J. Immunol. Meth. - 1989. - 121, № 2. - P. 203-208.

40. Candolfi M., Yagiz K., Foulad D. et al. Release of HMGB1 in response to proapoptotic glioma killing strategies: efficacy and neurotoxicity // Clin. Cancer Res. - 2009. - 15, № 13. - P. 4401-4414.

41. Lewis C., Murdoch C. Macrophage responses to hypoxia: implications for tumor progression and anticancer therapies // Amer. J. Pathol. - 2005. - 167, № 3. - P. 627-635.

42. Stout R.D., Jiang C., Matta B. et al. Macrophages sequentially change their functional phenotype in response to changes in microenvironmental influences // J. Immunol. - 2005. - 175, № 1. - P. 342349.

43. Chiang C.S., Chen F.H., Hong J.H. et al. Functional phenotype of macrophages depends on assay procedures // Int. Immunol. - 2008. - 20, № 2. - P. 215222.

44. Yun J.K., McCormick T.S., Villabona C. et al. Inflammatory mediators are perpetuated in macrophages resistant to apoptosis induced by hypoxia // Proc. Nat. Acad. Sci. USA. - 1997. - 94, № 25. P. 13903-13908.

45. Faoro V., Fink B., Taudorf S. et al. Acute in vitro hypoxia and high-altitude $(4,559 \mathrm{~m})$ exposure decreases leukocyte oxygen consumption // Amer. J. Physiol. Regul. Integr. Comp. Physiol. - 2011. - 300, № 1. R32-9.

46. Robinson M.A., Baumgardner J.E., Otto C.M. Oxygen-dependent regulation of nitric oxide production by inducible nitric oxide synthase // Free Rad. Biol. Med. - 2011. - 51, № 11. - P. 1952-1965.

47. Degrossoli A., Giorgio $S$. Functional alterations in macrophages after hypoxia selection // Exp. Biol. Med. (Maywood). - 2007. - 232, № 1. - P. 88-95.

48. Espey M.G. Tumor macrophage redox and effector mechanisms associated with hypoxia // Free Rad. Biol. Med. - 2006. - 41, № 11. - P. 1621-1628.

49. Klune J.R., Dhupar R., Cardinal J. et al. HMGB1: endogenous danger signaling // Mol. Med. - 2008. 14, № 7/8. - P. 476-484.

50. Vezzoli M., Castellani P., Campana L. et al. Redox remodeling: a candidate regulator of HMGB1 function in injured skeletal muscle // Ann. N.Y. Acad. Sci. - 2010. - 1209. - P. 83-90.

51. Tang D., Kang R., Zeh H.J. 3rd, Lotze MT. Highmobility group box 1, oxidative stress, and disease // Antioxid Redox Signal. - 2011. - 14, № 7. P. 1315-1335.

52. Tsung A., Klune J.R., Zhang X. et al. HMGB1 release induced by liver ischemia involves Toll-like receptor 4 dependent reactive oxygen species production and calcium-mediated signaling // J. Exp. Med. - 2007. 204, № 12. - P. 2913-2923.

Received 01.06.12 